\title{
Preoperative Oral Glucose Loading Decreasing Insulin Resistance with Homa-Ir Methods in Patient Undergoing Major Oncology Surgery
}

I Gede Budiarta, I Putu Pramana Suarjaya, Tjokorda Gde Agung Senapathi,

Ketut Wibawa Nada, Made Wiryana, Wayan Aryabiantara and Agus Adi Yastawa*

Department of Anesthesiology and Intensive Care, Sanglah General Hospital, Udayana University, Denpasar-Bali, Indonesia

Received: March 20, 2017; Accepted: May 12, 2017; Published: May 30, 2017

*Corresponding author: Agus Adi Yastawa, Department of Anesthesiology and Intensive Care, Sanglah General Hospital, Udayana University, Denpasar-Bali, Indonesia, Tel.: +628123984644; E-mail: agusadi.anestesi@gmail.com

\section{Abstract}

Background: Surgery and fasting may trigger a stress response that causes postoperative hyperglycemia and insulin resistance. Development of insulin resistance is associated with the increase of postoperative morbidity and mortality.

Objectives: The aim of this study was to verify whether preoperative oral glucose loading can reduce postoperative insulin resistance in subjects undergoing major surgery, and determined the effect of preoperative oral glucose loading frequency to the degree of insulin resistance.

Methods: Forty-five subjects who underwent major oncology surgery were randomly selected with concecutive random sampling method. The subjects were divided into 3 groups and each group consisted of 15 peoples, group one was given oral glucose solution preoperatively at night and early morning, group two the oral glucose was given only in the mornings preoperatively and for the control group were given only mineral water. The blood glucose and insulin level were measured at the morning before surgery and after surgery. The degree of insulin resistance was measured with HOMA-IR model. The difference between the groups was analyzed by LSD test, and data that were not normally distributed was analyzed by Mann Whitney test.

Results: The median value of postoperative HOMA-IR in the group one was 0.4 (IQR 0.36), group two (IQR 0.78), then the control group was 1.96 (IQR 1.7) with p value was $<0,001$, while the value of the difference in HOMA-IR for group one and group two was significantly different with p-value 0.007 .

Conclusion: Preoperative oral glucose loading may reduce blood sugar levels and insulin resistance postoperatively compared with subjects who fasted preoperatively, thus giving an oral glucose twice (evening and morning) preoperatively more effective in reducing insulin resistance postoperatively compared with subjects who were given oral glucose just only once in the mornings preoperatively.

Keywords: Glucose; Fasting; Insulin; Insulin Resistance

\section{Introduction}

Surgery is not only defined as an act of instrumentation to remove a pathological condition of a patient, further from the standpoint of metabolic surgery is a combination of various factors such as anesthesia, medication, blood loss, tissue damage and temperature changes that will lead to metabolic changes, which can cause postoperative stress response [1].

The stress response surgery will trigger the release of catabolic hormones such as catecholamines, cortisol, glucagon; and the release of cytokines such as interleukin- 6 and TNF- $\alpha$, which can independently give the rise to insulin resistance [2]. Insulin Resistance (IR) and hyperglycemia condition will be associated with increased postoperative morbidity and mortality [3].

Elective surgery usually would fast overnight for about 8 to 12 hours, which aims to reduce the risk of pulmonary aspiration. However, fasting will lead to a catabolic status that contributes onset of metabolic change including IR and increased ketogenesis [3].

Revised guidelines from several countries such as America, Canada and Europe which recommend reducing the duration of preoperative fasting with provision of water or a glucose solution for a few hours prior to elective surgery can improve patient comfort and safety [4]. It is also supported by Yu Yang's study in 2012 which stated that the administration of $10 \%$ glucose solution at $2-3$ hours before the induction of anesthesia is safe. Other studies comparing fasting by oral glucose administration, said that in subjects who were given oral glucose preoperatively had lower blood sugar levels and IR status $[5,6]$.

\section{Objectives}

This study aimed to determine whether preoperative oral administration of glucose can reduce the degree of postoperative 
IR in subjects who underwent major surgery, and to determine the effect of preoperative oral glucose administration frequency to the degree of IR.

\section{Methods}

This randomized single blind controlled trial study is conducted in December 2016 until February 2017 in the operating theater of Sanglah hospital. Forty-five subjects aged between 16-65 years who will undergo major surgery with general anesthesia in surgical oncology incorporated into this study. Whereas subjects with diabetes mellitus or with $\mathrm{HbA1c}>$ $6.5 \%$, subjects with BMI less than $17 \mathrm{kgs} / \mathrm{m}^{2}$ and more than 30 $\mathrm{kgs} / \mathrm{m}^{2}$, subjects with physical status ASA III - V, subjects with hormonal therapy and steroids as well as subjects combined with regional anesthesia technic were excluded in this study. The drop out criteria was bleeding during the operation are more than $30 \%$ of Estimated Blood Volume (EBV) and when the operating time are more than 360 minutes.

The Forty-five samples of this study were divided into three groups: control group $(n=15)$, the first treatment group $(n=15)$ and second treatment group $(n=15)$. The first treatment group got a solution which contained 75 grams of glucose monohydrate and dissolved in $300 \mathrm{ml}$ water in the evening before the surgery at 21:00 pm and the morning before surgery at 05:00 am, subsequent to the second treatment group was only given solution which containing 75 grams of glucose monohydrate and dissolved in $300 \mathrm{ml}$ water in the morning before surgery at 05:00 am, while the control group was not given a glucose solution, which was given only mineral water in the evenings at
21:00 pm and morning at 05.00 am preoperatively. Blood sample of the subjects was taken to examine the blood sugar levels, insulin levels and calculation of HOMA-IR before surgery at 05.00 am before the patient took a solution of glucose and in the recovery room at $14.00 \mathrm{pm}$ postoperatively, measurement of IR using homeostasis model assessment insulin resistance (HOMAIR) formula. HOMA-IR was calculated by the following formula: HOMA IR = (Blood Glucose X insulin) / 405 [7,8]. Glucose level was expressed in $\mathrm{mg} / \mathrm{dl}$ and insulin levels included in $\mu \mathrm{U} / \mathrm{ml}$. Limit of normal values for resistance insulin was 1.85 where the higher HOMA-IR mean higher degree of insulin resistance [9]. Collected data were analyzed statistically with test for normality using Shapiro - Wilk and for data which was classified as not normal distribution followed by Kruskal - Wallis test, also tested the homogeneity of variance with the Levene test. Furthermore, to know the difference between groups was tested with Post Hoc LSD, while because the distribution data of the difference in insulin and HOMA-IR was not normally distributed, they were analyzed by Mann - Whitney test.

\section{Results}

The total number of samples in this study that met the acceptance criteria as much as 45 samples, each treatment group and the control sample amounted to 15 people. All the taken samples met the acceptance criteria and none met the criteria drop out. From the characteristics of the sample by age, gender, ASA physical status, BMI, duration of surgery and the amount of bleeding in accordance listed in table 1 of all treatment groups had comparable.

\begin{tabular}{|c|c|c|c|c|c|}
\hline \multirow[b]{2}{*}{ Variable } & & \multicolumn{3}{|c|}{ Sample groups } & \multirow[b]{2}{*}{$\mathrm{p}$ value } \\
\hline & & $1^{\text {st }}$ treatment $(n=15)$ & $\begin{array}{l}2^{\text {nd }} \text { treatment } \\
\qquad(\mathrm{n}=15)\end{array}$ & Control (n=15) & \\
\hline Age (Years) & Mean \pm SEM & $47,3+10,5$ & $45,9+14$ & $46,8+10,9$ & $0,943^{\mathrm{a}}$ \\
\hline \multirow{2}{*}{ Sex } & Male n(\%) & $3(20)$ & $6(40)$ & $3(20)$ & \multirow{2}{*}{$0,360^{\mathrm{b}}$} \\
\hline & Female n(\%) & $12(80)$ & $9(60)$ & $12(80)$ & \\
\hline BMI $\left(\mathrm{kg} / \mathrm{m}^{2}\right)$ & Mean \pm SEM & $22,1+2,0$ & $23,8+2,7$ & $24,5+3,8$ & $0,075^{c}$ \\
\hline \multirow{2}{*}{ Physical status ASA } & ASA $1 \mathrm{n}(\%)$ & $6(40)$ & $4(26,7)$ & $5(33,3)$ & \multirow{2}{*}{$0,741^{\mathrm{b}}$} \\
\hline & ASA $2 n(\%)$ & $9(60)$ & $11(73,3)$ & $10(66,7)$ & \\
\hline $\begin{array}{l}\text { Duration of operation } \\
\text { (minutes) }\end{array}$ & Mean \pm SEM & $188,6+70,8$ & $166,3+60,8$ & $179,7 \pm 51,8$ & $0,611^{\mathrm{a}}$ \\
\hline Volume of bleeding (ml) & Mean \pm SEM & $158,3+161$ & $113,3+108$ & $104+77,8$ & $0,787^{c}$ \\
\hline \multicolumn{6}{|l|}{$\begin{array}{l}\text { a : One Way Anova test } \\
\text { b : Chi-Square test } \\
\text { c : Kruskal-Wallis test }\end{array}$} \\
\hline
\end{tabular}


Comparison of mean and median value in all groups of this studies in preoperative period shown in Table 2, which were obtained by the calculation of random blood sugar, insulin and HOMA-IR preoperatively in all treatment groups were statistically significant different with $\mathrm{p}$ value $0.033,0.046$ and 0.019 .

Further calculations postoperative random blood sugar and insulin levels in all treatment groups were statistically significant different with $\mathrm{p}$ value $<0.001$ and 0.001 like it shown in table 3. Postoperative median HOMA-IR in the first treatment group was 0.4 (IQR 0.36), in the second treatment group was 0.46 (IQR 0.78) and in the control groups was 1.96 (IQR 1.7) with $p$ value $<0.001$. So the calculation value of HOMA-IR preoperatively in all treatment groups were statistically significant different, whereas in all groups at preoperative and postoperative obtained an increased of HOMA-IR in the control group, while in the treatment groups the HOMA-IR seemed to be decrease like it shown in Figure 1.

Table 2. Preoperative Blood Sugar, Insulin and HOMA- IR Values

\begin{tabular}{|c|c|c|c|c|c|}
\hline \multirow[b]{2}{*}{ Variable } & & \multicolumn{2}{|c|}{ Sample Groups } & \multirow[b]{2}{*}{$\begin{array}{l}\text { Control } \\
(n=15)\end{array}$} & \multirow[b]{2}{*}{$\begin{array}{c}\mathrm{p} \\
\text { value }\end{array}$} \\
\hline & & $\begin{array}{c}1^{\text {st }} \\
\text { treatment } \\
(n=15)\end{array}$ & $\begin{array}{c}2^{\text {nd }} \\
\text { treatment } \\
(n=15)\end{array}$ & & \\
\hline $\begin{array}{l}\text { Blood } \\
\text { Sugar }\end{array}$ & $\begin{array}{c}\text { Mean + } \\
\text { SEM }\end{array}$ & $95,7+8,1$ & $89,4+7,6$ & $\begin{array}{c}99,5 \pm \\
13,8\end{array}$ & $0,033^{\mathrm{a}}$ \\
\hline Insulin & $\begin{array}{c}\text { Median ( } \\
\text { IQR) }\end{array}$ & $6,3(4,21)$ & $2,96(3,9)$ & $6,3(6,9)$ & $0,046^{\mathrm{b}}$ \\
\hline $\begin{array}{l}\text { HOMA- } \\
\text { IR }\end{array}$ & $\begin{array}{c}\text { Median ( } \\
\text { IQR) }\end{array}$ & $1,6(1,2)$ & $0,7(1,0)$ & $1,7(1,8)$ & $0,019^{b}$ \\
\hline
\end{tabular}

a : One Way Anova test

$\mathrm{b}$ : Kruskal-Wallis test

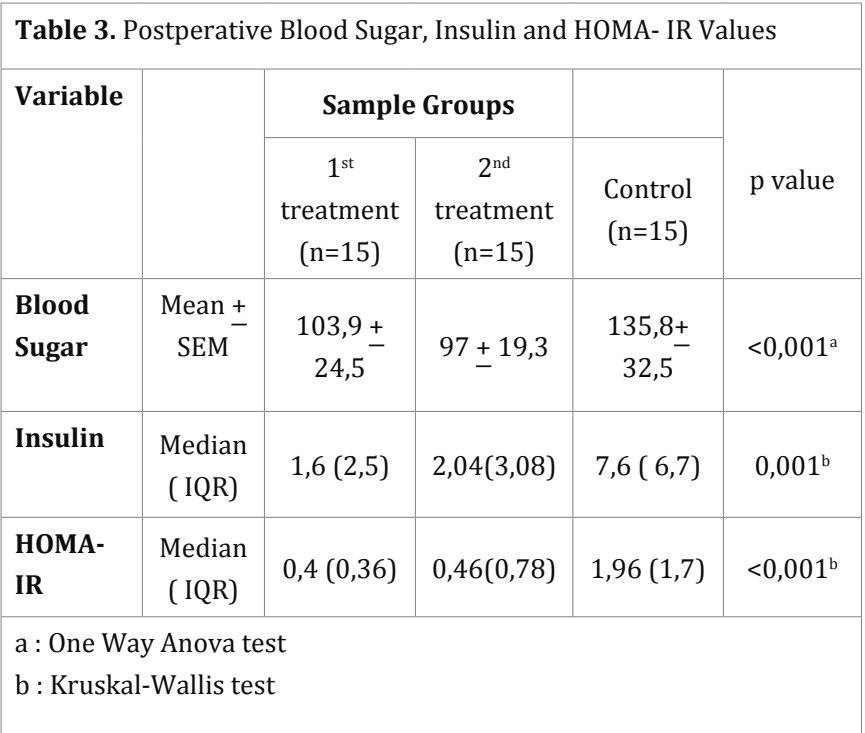

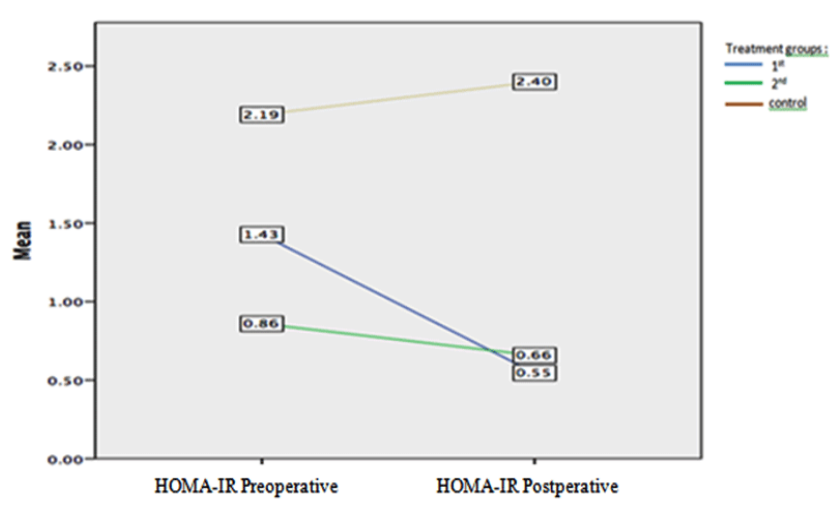

Figure 1: Graph Changes in HOMA-IR preoperative and postoperative

The Difference $(\Delta)$ in random blood sugar among all groups were significantly different with $\mathrm{p}$ value 0.003 ; so as when compared to the difference between random blood sugar between first treatment groups to the control group and the second treatment group to the controls also obtained significantly different with $\mathrm{p}$ values of both is 0,003 and 0,048 , but the comparison of the difference between random blood sugar between first treatment and second treatment group obtained was not significantly different with $p$ value 0.918 , while the difference in HOMA-IR among all of groups were significantly different with $\mathrm{p}$ value 0.036 , where the smallest median value is in the first treatment group when compared between first treatment and second treatment groups seem statistically significant different with $\mathrm{p}$ value 0,007 like it shown in table 4 .

Table 4. Difference $(\Delta)$ Blood Sugar, Insulin and HOMA- IR Values Preoperative and Postoperative

\begin{tabular}{|c|c|c|c|c|c|}
\hline \multirow[t]{2}{*}{ Variable } & & \multicolumn{2}{|c|}{ Sample Groups } & \multirow[b]{2}{*}{$\begin{array}{l}\text { Control } \\
(n=15)\end{array}$} & \multirow[b]{2}{*}{$\begin{array}{c}\mathrm{p} \\
\text { value }\end{array}$} \\
\hline & & $\begin{array}{c}1^{\text {st }} \\
\text { treatment } \\
(n=15)\end{array}$ & $\begin{array}{c}2^{\text {nd }} \\
\text { treatment } \\
(n=15)\end{array}$ & & \\
\hline $\begin{array}{l}\Delta \text { blood } \\
\text { Sugar }\end{array}$ & Mean + SEM & 8,3+23,3 & $7,6+20,3$ & $\begin{array}{c}36,3 \pm \\
29,1\end{array}$ & 0,003 \\
\hline $\begin{array}{l}\Delta \\
\text { Insulin }\end{array}$ & $\begin{array}{r}\text { Median ( } \\
\text { IQR) }\end{array}$ & $-0,4(5,2)$ & $\begin{array}{c}0,12 \\
(3,47)\end{array}$ & $\begin{array}{l}-1,2 \\
(10)\end{array}$ & 0,089 \\
\hline $\begin{array}{l}\Delta \text { HOMA- } \\
\text { IR }\end{array}$ & $\begin{array}{l}\text { Median ( } \\
\text { IQR) }\end{array}$ & $-0,94(1,0)$ & $\begin{array}{l}0,02( \\
0,75)\end{array}$ & $\begin{array}{c}0,24 \\
(3,04)\end{array}$ & 0,036 \\
\hline \multirow[b]{2}{*}{ Variable } & \multicolumn{5}{|c|}{ P value } \\
\hline & $\begin{array}{c}1^{\text {st }} \\
\text { Treatment- } \\
\text { Control }\end{array}$ & \multicolumn{2}{|c|}{$2^{\text {nd }}$ Treatment-Control } & \multicolumn{2}{|c|}{$\begin{array}{l}1^{\text {st }} \text { Treatment- } \\
2^{\text {nd }} \text { Treatment }\end{array}$} \\
\hline $\begin{array}{l}\Delta \text { blood } \\
\text { Sugar }\end{array}$ & $0,003^{\mathrm{a}}$ & \multicolumn{2}{|c|}{$0,048^{\mathrm{a}}$} & \multicolumn{2}{|c|}{$0,941^{\mathrm{a}}$} \\
\hline$\Delta$ Insulin & $0,217^{\mathrm{b}}$ & \multicolumn{2}{|c|}{$0,775^{\mathrm{b}}$} & \multicolumn{2}{|c|}{$0,011^{\mathrm{b}}$} \\
\hline $\begin{array}{l}\Delta \text { HOMA- } \\
\text { IR }\end{array}$ & $0,081^{b}$ & \multicolumn{2}{|c|}{$0,486^{\mathrm{b}}$} & \multicolumn{2}{|c|}{$0,007^{\mathrm{b}}$} \\
\hline $\begin{array}{l}\mathrm{a}: \text { Post Ho } \\
\mathrm{b}: \text { Mann-h}\end{array}$ & $\begin{array}{l}\text { LSD test } \\
\text { hitney test }\end{array}$ & & & & \\
\hline
\end{tabular}




\section{Discussion}

Insulin plays an important role in various metabolic processes in the body, especially the metabolism of glucose. This hormone is a very crucial role in the utilization of glucose by almost all body tissues, especially in muscle, fat and liver. It is known there are several stages in the process of insulin secretion after stimulation by glucose molecules. The first stage is the process of glucose passing through the cell membrane. To be able to pass through the membrane of beta cells needed the help of other compounds. Glucose transporter (GLUT) is a compound of amino acids contained in the various cells that play a role in the metabolism of glucose [10].

Stress conditions caused by surgical intervention or critical illness, can cause various metabolic changes including excessive glucose production and the disruption of glucose uptake in peripheral tissues that depend on insulin, which ultimately leads to the conditions of hyperglycemia. Where the presence of high blood sugar may impaired the body's immune response. Trauma of the surgery accompanying stress thus activates the endocrine system. The result is increased production of glucose in the liver, barriers secretion on insulin action and insulin resistance, which then again will increase the incidence of hyperglycemia [11].

Further studies conducted by Brownlee related to stress conditions during the surgery showed that in the early phase after surgery, resistance is mostly located in peripheral location, which is mainly in the muscles, and a few days later resistance is more prevalent in the liver. Peripheral tissue mainly in the muscle is the main sensitive organ to insulin. In the muscles, found a quickly reduction of specific proteins to transport glucose after surgery, in this case the quantity of GLUT-4 (glucose transporter-4) as a response to the stimulus of glucose is reduced under conditions of stress, it can explain the cause of the uptake block of glucose into the muscle. In these conditions, excess of glucose can enter the cells only through the mechanism of glycolysis, which in conditions of excessive glycolysis, the free radicals oxygen formed in the mitochondria. These free radicals are, at some point will lead to large changes in metabolism even further on gene expression that seems to be applied to determine the cause of postoperative IR, gene expression is altered as a result of surgical stress to be an up-regulation of genes for inflammation in this case the release of cytokines may play a role in the development of IR $[10,12]$.

In this study, it appears that administration of oral glucose two times (evening and early morning preoperatively) and giving once (early morning preoperative) is effective for preventing an increase in blood sugar and IR when compared with the control group, but the comparison of administration oral glucose twice time and giving once has no significant difference in preventing postoperative increase in blood sugar. If compared in IR condition, administration of oral glucose twice time found better in reducing postoperative insulin resistance than once time.

\section{Conclusion}

Major surgery causes an increase in postoperative blood glucose levels and IR, then by providing oral glucose preoperatively can lowering blood glucose levels and IR postoperatively compared with subjects who fasted preoperatively and administration of oral glucose two times (evening and morning) before surgery more effective in lowering of postoperative IR compared to subjects who given oral glucose just once time (only morning) preoperatively, however the result of this study may be more generalizable when used larger number of subject.

\section{Acknowledgements}

This study was approved by the institutional ethics committee. The authors received no external funding in conducting this study. The authors report that there is no conflict of interest to declare.

\section{References}

1. Hager P. Systemic stress response and hyperglycemia after abdominal surgery in rat and man. 2008.

2. Ljungqvist 0. Nutritional Support in the Perioperative Period Normalization of glucose in ICU reduces mortality \& morbidity. $2005 ; 15-22$.

3. Yokoyama T, Suwa K, Yamasaki F, Yokoyama R, Yamashita K, Sellden E. Intraoperative infusion of acetated Ringer solution containing glucose and ionized magnesium reduces ketogenesis and maintains serum magnesium. Asia Pac J Clin Nutr. 2008;17(3):525-529.

4. Ludwig RB, Paludo J, Fernandes D, Scherer F. Lesser time of preoperative fasting and early postoperative feeding are safe? Arq Bras Cir Dig. 2013;26(1):54-58.

5. Yu Yang, Zhou Yan Bing, Jiao Xue Long, Chen Dong, Wang Zhi Hao. Effects and Safety of Preoperative Oral Carbohydrate in Radical Distal Gastrectomy - A Randomized Clinical Trial. J Cancer Sci Ther. 2012;4(45):116-119.

6. Perrone F, Da-Silva-Filho AC, Adôrno IF, Anabuki NT, Leal FS, Colombo $\mathrm{T}$, et al. Effects of preoperative feeding with a whey protein plus carbohydrate drink on the acute phase response and insulin resistance. A randomized trial. Nutr J. 2011;10(1):66. doi: 10.1186/1475-2891$10-66$

7. Matthews DR, Hosker JR, Rudenski AS, Naylor BA, Treacher DF, Turner RC. Homeostasis model assessment: insulin resistance and beta-cell function from fasting plasma glucose and insulin concentrations in man. Diabetologia. 1985;412-9.

8. Singh B, Saxena A. Surrogate markers of insulin resistance: A review. World J Diabetes. 2010;1(2):36-47. doi: 10.4239/wjd.v1.i2.36

9. Radziuk J. Homeostastic model assessment and insulin sensitivity/ resistance. Diabetes. 2014;63(6):1850-1854.

10. Ljungqvist 0 . Modulating postoperative insulin resistance by preoperative carbohydrate loading. Best Pract Res Clin Anaesthesiol. 2009;23(4):401-409.

11.Gardner,B. Perioperative hyperglycaemia. Chir Gastroenterol Interdiszip. 2004;20(3):192-195.

12. Ljungqvist O. Metabolic Responses to Surgical Stress. 2015. 